\title{
A JUDICIALIZAÇÃO DO REFÚGIO NO STJ: DEFERÊNCIA AO EXECUTIVO E INCOERÊNCIA INTERPRETATIVA
}

\section{THE JUDICIALIZATION OF REFUGE IN THE STJ: DEFERENCE TO THE EXECUTIVE BRANCH AND INTERPRETATIVE INCOHERENCE}

\author{
Breno Baía Magalhães \\ Universidade Federal do Pará - UFPA - (Belém, Pará, Brasil) \\ Gabriella Thaís Sousa Corrêa \\ Universidade Federal do Pará - UFPA - (Belém, Pará, Brasil) \\ Recebimento: 12 fev. 2019 \\ Aceitação: 18 abr. 2019
}

\begin{abstract}
Como citar este artigo / How to cite this article (informe a data atual de acesso / inform the current date of access):
MAGALHÃES, Breno Baía; CORRÊA, Gabriella Thaís Sousa. A judicialização do refúgio no STJ: deferência ao Executivo e incoerência interpretativa. Revista da Faculdade de Direito UFPR, Curitiba, PR, Brasil, v. 64, n. 1, p. 137164, jan./abr. 2019. ISSN 2236-7284. Disponível em: <https://revistas.ufpr.br/direito/article/view/64908>. Acesso em: 30 abr. 2019. DOI: http://dx.doi.org/10.5380/rfdufpr.v64i1.64908.
\end{abstract}

\section{RESUMO}

O presente artigo pretende realizar uma análise da jurisprudência do Superior Tribunal de Justiça (STJ), a fim de identificar quais hipóteses de judicialização do refúgio, segundo as categorias estipuladas por Jubilut (2011), apresentam-se naquela corte, e se há ou não deferência judicial às decisões do Poder Executivo sobre expulsão ou denegação do status de refugiado. O artigo, de cunho empírico, analisou o inteiro teor de 13 decisões do STJ, entre acórdãos e decisões monocráticas. A metodologia empregada é institucionalista, focada na construção jurisprudencial das regras e seu impacto na concretização de suas finalidades. O estudo conclui que o STJ desenvolveu uma doutrina de grande deferência ao Poder Executivo, salientando a impossibilidade de revisão judicial do mérito das decisões administrativas em temas relacionados à política exterior do Brasil. Por fim, argumentamos, como futura pauta para pesquisas, que a tendência judicial de total deferência pode indicar uma posição do Estado brasileiro a respeito de uma política exterior de não recepção de refugiados.

\section{PALAVRAS-CHAVE}

Judicialização do refúgio. Superior Tribunal de Justiça. Discricionariedade administrativa.

\begin{abstract}
The present article intends to analyze the jurisprudence of the Brazilian Superior Court of Justice (Superior Tribunal de Justiça, or STJ), in order to identify which hypotheses of judicialization of refuge, according to the categories stipulated by Jubilut (2011), are presented in that court and if there is or not judicial deference to the Executive branch decisions on expulsion or denial of refugee status. This empirical article analyzed the entire content of 13 decisions of the STJ, among full bench and monocratic decisions. The methodology employed is institutionalist, focused on the jurisprudential construction of the rules and their impact on the achievement of their purposes. The study concludes that the STJ developed a doctrine of great deference to the Executive branch, stressing the
\end{abstract}


impossibility of judicial review of the merits of administrative decisions on issues related to Brazil's foreign policy. Finally, we argue, as a future agenda for research, that the judicial trend of total deference may indicate a position of the Brazilian State regarding a foreign policy of non-reception of refugees.

\section{KEYWORDS}

Judicialization of refuge. Brazilian Superior Court of Justice. Administrative discretion.

\section{INTRODUÇÃO: A JUDICIALIZAÇÃO DO REFÚGIO}

Segundo Jubilut (2011, p. 163), a judicialização do refúgio é um dos meios de ação na busca pela proteção integral dos refugiados, na medida em que se trata de recurso ao Poder Judiciário para a efetivação de direitos, os quais envolvem tanto a concretização dos direitos humanos dos refugiados quanto de direitos decorrentes do Direito Internacional dos Refugiados.

O refúgio é regulamentado por uma normativa internacional de caráter universal, a Convenção de 1951 da ONU, que não apenas assegura direitos aos refugiados, mas também traz o próprio conceito de refugiado, posteriormente alargado pelo Protocolo de 1967. O Estado brasileiro regulamentou os procedimentos relativos ao refúgio na Lei Federal 9.474/97. Tais instrumentos formam a base para a judicialização do refúgio no Brasil por se tratar de tratados e leis aplicáveis pelo Poder Judiciário na busca pela efetivação dos direitos acima afirmados.

Quanto aos direitos dos refugiados, podem ser divididos em dois grupos: os direitos decorrentes do Direito Internacional dos Direitos Humanos, os chamados direitos humanos dos refugiados - definidos como aqueles cujos titulares são todos os seres humanos, independentemente de qualquer situação ou característica -, e os decorrentes do Direito Internacional dos Refugiados, que são aqueles previstos nos tratados específicos da ONU ou da OEA (JUBILUT, 2011, p. 170). Estes últimos são conceituados como aqueles relativos aos princípios de proteção assegurados por este ramo específico do Direito Internacional e aqueles decorrentes do próprio status de refugiado; entre eles, por exemplo, o direito à concessão do refúgio.

A judicialização do refúgio também é consequência do próprio conceito de refugiado trazido pela Convenção de 1951, tendo em vista que o reconhecimento da condição de refugiado é ato revestido de caráter jurídico, declaratório e que deve ser assegurado quando preenchidas as condições previstas na norma legal (JUBILUT, 2011, p. 173). Assim, por estarmos diante de um direito subjetivo daqueles que satisfizerem os critérios legais, obviamente tal direito pode ser objeto de análise pelo Poder Judiciário (JUBILUT, 2011, p. 174). 
Ainda no atinente à judicialização do refúgio, o Judiciário pode atuar, em nosso país, nas diversas fases que o constituem: 1) no momento de entrada do solicitante no território nacional, em prol da garantia da não devolução e da não penalização pela entrada irregular; 2) na fase de determinação do status de refugiado, exercendo o controle formal e material do procedimento administrativo de concessão do refúgio e 3) no momento de integração do refugiado ao País, em prol da proteção do direito de acesso dos refugiados às políticas públicas e assistência social, impulsionando o processo de integração local destas pessoas (MORAES, 2014, p. 179).

Nesse sentido, portanto, as hipóteses de judicialização do refúgio podem ser divididas em: a) casos sobre o resultado do processo de solicitação de refúgio, nos quais se debatem suas questões formais; b) casos em que se debate o conceito de refugiado e sua aplicação enquanto direito; c) casos que envolvem o gozo de direitos humanos dos refugiados; d) casos envolvendo conflitos de direitos entre a proteção dos refugiados e os nacionais em geral e e) casos nos quais os princípios do Direito Internacional dos Refugiados são o objeto central (JUBILUT, 2011, p. 175).

A construção da judicialização do refúgio por parte de Jubilut (2011) se apresenta como um argumento que exige comprovação empírica, a partir das cinco categorias construídas dogmaticamente no parágrafo anterior. Ainda que não tenha apresentado uma pesquisa sistemática sobre a jurisprudência dos tribunais brasileiros, a autora conclui que "a jurisprudência sobre o tema ainda é escassa e não apresenta uniformidade; além de demonstrar em sua grande maioria uma tendência a deferir os casos ao Poder Executivo” (JUBILUT, 2011, p. 175).

O presente artigo pretende, assim, a partir das contribuições de Jubilut (2011), realizar uma análise da jurisprudência do Superior Tribunal de Justiça, a fim de identificar quais hipóteses de judicialização se apresentam naquela corte e se a hipótese da deferência ao Executivo se constata. O tribunal superior foi escolhido por ser o órgão competente para uniformizar a interpretação da legislação infraconstitucional federal, o que nos interessa por conta da lei federal sobre refúgio e também por ser competente para julgar os Mandados de Segurança e Habeas Corpus propostos em face de Ministro de Estado (art. 105, I, b CRFB/88), agente que preside o Comitê Nacional para os Refugiados (Conare).

A exposição descritiva das decisões será seguida por considerações sobre seu conteúdo, cotejando-as com as decisões constitucionais e internacionais e com a construção doutrinária mais recente. A metodologia empregada para a leitura dos dados coletados é institucionalista (SCOTT, 2004, p. 408), focada na identificação dos fatores que estabelecem as regras que condicionam o comportamento social. Tomando por pressuposição que a estrutura legal sobre o refúgio constitui o esquema institucional que condiciona a atuação do STJ, pretendemos, a partir da análise de suas 
decisões, identificar como o Tribunal constrói tais regras, quais fatores condicionam sua atuação e quais funções podem ser identificadas.

No último tópico, serão desenvolvidas algumas conclusões sobre a análise global dos casos, e, entre elas, a principal é a de que as suspeitas de Jubilut estavam corretas no caso do STJ: há uma grande deferência ao Poder Executivo e uma resistência judicial em realizar a revisão das decisões administrativas. Por fim, argumentamos, como futura pauta para pesquisas, que a tendência judicial de total deferência pode indicar uma posição do Estado brasileiro a respeito de uma política exterior de não recepção de refugiados.

\section{A JURISPRUDÊNCIA DO SUPERIOR TRIBUNAL DE JUSTIÇA SOBRE REFÚGIO}

Em consulta pelos termos "refúgio”, “Conare” e "refugiados” no sítio eletrônico do STJ foram encontrados 23 acórdãos e 54 decisões monocráticas que traziam tal expressão.

Dentre as decisões monocráticas, apesar de conterem a expressão refugiados, 16 delas a utilizaram em sentido diverso daquele estipulado pelas normas internacionais, como, por exemplo, no RHC n 54.059/PR (2014), no qual há discussão sobre a possibilidade de os pacientes, condenados criminalmente, fugirem antes do trânsito em julgado da condenação e, “refugiados”, usufruírem do produto da atividade criminal. Ademais, 13 dessas decisões estão duplicadas e 22 tratam somente de questões processuais que não adentram o mérito da demanda. Dessa forma, serão analisadas somente as três decisões monocráticas restantes.

Do mesmo modo, dentre os acórdãos, o Recurso Especial n $n^{\circ}$ 1.487.032/SP, por exemplo, tratou de decisão que não analisou o mérito da pretensão, e, por conta disto, nossa análise se restringirá aos dez acórdãos restantes.

Portanto, as decisões analisadas foram: 1) Recurso Especial n ${ }^{0} 1.475 .580$ - RJ (STJ, $4^{\mathrm{a}}$ Turma, Relator: Ministro Luis Felipe Salomão, DJ: 19/05/2017); 2) Habeas Corpus nº 333.902 - DF (STJ, Primeira Seção, Relator: Ministro Humberto Martins, DJ: 22/10/2015); 3) Recurso Especial $n^{\circ}$ 1.174.235 - PR (STJ, 2 ${ }^{\mathrm{a}}$ Turma, Relator: Ministro Herman Benjamin, DJ: 28/02/2012); 4) Mandado de Segurança (MS) no 17.611 - DF (STJ, Primeira Seção, Relator: Ministro Arnaldo Esteves Lima, DJ: 25/03/2013), 5) MS nº 12.510 - DF (STJ, Primeira Seção, Relatora: Ministra Denise Arruda, DJ: 10/09/07), 6) MS no 11.417 - DF (STJ, Primeira Seção, Relator: Ministro José Delgado, DJ: 02/04/07); 7) Recurso Especial $n^{0} 1.163 .011$ - RS (STJ, Relator: Ministro Sérgio Kukina, Data da Publicação: 29/09/17); 8) Habeas Corpus nº 98.735 - DF (STJ, Primeira Seção, Relatora: Ministra Denise Arruda, DJ: 20/10/08); 9) Habeas Corpus n 412.840 (STJ, Relator: Ministro Sérgio Kukina, 
Data da Publicação: 20/10/17); 10) Agravo Regimental no Mandado de Segurança n ${ }^{0} 17.612$ - DF (STJ, Primeira Seção, Relator: Ministro Mauro Campbell Marques, DJ: 18/11/11); 11) Mandado de Segurança nº 13.383 - DF (STJ, Primeira Seção, Relator: Ministro Carlos Fernandes Mathias, DJ: 04/08/08); 12) Habeas Corpus nº 115.183 - DF (STJ, 6 a Turma, Relator: Ministro Haroldo Rodrigues, DJ: 08/09/11); e, por fim, 13) Habeas Corpus n 36.033 - DF (STJ, Primeira Seção, Relator: Ministro Francisco Falcão, DJ: 14/03/05).

A pesquisa utilizou o inteiro teor dos acórdãos e das decisões monocráticas, não se restringindo, portanto, à leitura das ementas dos julgados. Não fixamos um marco temporal inicial, contabilizando, assim, todas as decisões da Corte desde a sua criação (1990); contudo, a pesquisa delimitou o prazo final em julho de 2018. A exposição das decisões seguiu a reconstrução argumentativa dos votos dos ministros, no sentido de tentar extrair a razão de decidir do caso, bem como eventuais particularidades da demanda em julgamento. Quando cabível, a pesquisa fez menção ao posicionamento dos votos vencidos, principalmente, para reforçar a identificação do argumento vencedor.

A exposição das decisões seguiu a seguinte ordenação: 1) inicialmente, os acórdãos, por representarem a posição do órgão fracionário do STJ competente para decidir tais espécies de demandas (no caso, a $1^{\text {a }}$ Seção), e, em seguida, as decisões monocráticas e 2) os julgados, dispostos de forma decrescente por ano de julgamento, para que tenhamos uma visão dos posicionamentos mais recentes da Corte.

\section{EXPOSIÇÃO E COMENTÁRIOS SOBRE OS CASOS DO STJ SOBRE REFÚGIO}

\subsection{ACÓRDÃOS}

a) Recurso Especial n ${ }^{\circ} 1.475 .580 / \mathrm{RJ}$ (4 ${ }^{\mathrm{a}}$ Turma, 2017)

O Recurso Especial em apreço teve como discussão principal a possibilidade de expedição de registro civil de nascimento, no Brasil, para criança estrangeira refugiada que não portava documento que atestava sua identidade e requeria ao Judiciário tal documentação para poder matricular-se e gozar de cobertura sanitária.

O recorrente foi o Ministério Público do Estado do Rio de Janeiro, que se insurgiu contra decisão do Tribunal de Justiça daquele estado que confirmou a decisão de $1^{\circ}$ grau que, liminarmente, havia determinado a expedição de mandado de registro civil de nascimento a menor refugiada que adentrou o território nacional desprovida de qualquer documento de identidade. 
A despeito de toda a discussão ocorrida no caso, sobre a conceituação de nacional brasileiro à luz da Constituição e da Lei de Registros Públicos (Lei nº 6.015/73), que levou o STJ a declarar a impossibilidade de se conferir o registro civil de nascimento a um estrangeiro (porquanto a lei vincula tal expedição apenas ao brasileiro nato), o ponto que merece destaque neste caso diz respeito ao exercício, pelos refugiados, de seus direitos fundamentais.

Quanto ao referido ponto, o Superior Tribunal de Justiça firmou entendimento no sentido de que, para que o refugiado possa exercer seus direitos fundamentais, basta que solicite a documentação própria de estrangeiro, nos termos dos artigos $6^{\circ}, 21$ e 22 da Lei 9.474/97. Isso porque o ordenamento jurídico nacional, em consonância com os tratados e convenções internacionais sobre refugiados, teria previsto solução adequada e eficiente para os refugiados e solicitantes de refúgio no que concerne à sua regularização documental, qual seja, o direito de ter o protocolo provisório no momento da solicitação do refúgio e de ter o Registro Nacional de Estrangeiro (RNE) expedido quando confirmado seu status de refugiado.

O Ministro Relator, Luís Felipe Salomão, em seu voto, ressaltou que ambos os documentos permitem que o estrangeiro residente no Brasil goze de todos os direitos fundamentais reconhecidos aos brasileiros, e, dessa forma, o Registro Nacional de Estrangeiro seria o documento de identidade equivalente ao registro civil de pessoas naturais, garantindo ao refugiado o acesso aos serviços públicos essenciais, como saúde, educação e a expedição de carteira de trabalho.

Ressaltou também o ministro que os tratados internacionais e os direitos neles previstos deveriam ser interpretados em conformidade com a legislação de cada país, sem ofendê-la. Tendo em vista que o direito de obtenção do protocolo provisório e do Registro Nacional de Estrangeiro foi a solução encontrada, por meio da expressão máxima de soberania, pela República Federativa do Brasil quanto aos problemas relacionados à documentação dos refugiados, não poderia o Poder Judiciário se imiscuir na questão.

Ainda segundo o relator, somente se não houvesse mecanismo específico para a solução da demanda se abriria ao Judiciário a possibilidade de suprir tal lacuna e salvaguardar os direitos discutidos no caso concreto. Porém, considerando que nosso sistema jurídico disporia de instrumentos adequados à proteção dos refugiados, o Superior Tribunal de Justiça deu provimento ao recurso especial a fim de determinar o cancelamento do registro civil de nascimento outrora expedido.

A decisão do Superior Tribunal de Justiça de equiparar a certidão de nascimento brasileira ao Registro Nacional de Estrangeiro está em consonância com o sistema de proteção dos refugiados, tendo em vista que a Lei 9.474/97 prevê em seu artigo $6^{\circ}$ que, como forma de identificação, o refugiado terá direito, nos termos da Convenção sobre o Estatuto dos Refugiados de 1951, à cédula 
de identidade comprobatória de sua condição jurídica, carteira de trabalho e documento de viagem.

Nesse mesmo sentido, o artigo 21 da lei de refúgio estabelece que será emitido um protocolo do requerimento em favor do solicitante de refúgio e de seu grupo familiar, que autorizará sua estada no território nacional até a decisão final do processo, com possibilidade de expedição de carteira de trabalho provisória e no qual serão averbados os nomes dos menores de 14 anos, que serão titulares dos mesmos benefícios que seus responsáveis.

Como se pode perceber, a legislação brasileira referente aos refugiados dispõe acerca dos direitos que as crianças e adolescentes dependentes de refugiados titularizam, não sendo a certidão de nascimento brasileira requisito para que seja reconhecida sua identidade formal, nem para que possam ser matriculados em estabelecimento de ensino ou para que recebam atendimento médico pela rede pública de saúde. Todos esses direitos podem ser exercidos a partir do Registro Nacional de Estrangeiro, nos termos da Lei $n^{\circ}$ 9.474/97 e de uma interpretação dos direitos fundamentais da Constituição.

Por fim, vale destacar que a decisão identificou uma margem de não atuação judicial no caso do deferimento da documentação do solicitante de refúgio ou do refugiado: caso haja uma previsão legal formal, indicando documento suficiente para que o refugiado possa gozar de direitos fundamentais, não poderá o Poder Judiciário criar outra alternativa. Por outro lado, o ministro sugere uma interpretação do tratado à luz da legislação nacional e não o contrário, estabelecendo uma relação de precedência que poderá contrariar a lógica de garantir uma interpretação mais favorável aos Direitos Humanos.

Dessa forma, parece-nos que o entendimento do STJ no acórdão em apreço está de acordo com uma interpretação protetiva dos direitos dos refugiados.

b) $H C n^{\circ} 333.902 / \mathrm{DF}\left(3^{\mathrm{a}}\right.$ Seção, 2015)

O segundo caso a ser analisado é o do Habeas Corpus nº 333.902/DF, impetrado pela Defensoria Pública da União em face de ato do Ministro de Estado da Justiça que determinou a expulsão de paciente do território nacional pelo cometimento do crime hediondo de tráfico internacional de entorpecentes, após a concessão do refúgio.

A tese consolidada no Habeas Corpus em apreço foi a de que seria nula a portaria de expulsão editada contra refugiado antes de instaurado e concluído regular processo administrativo de perda de refúgio, não podendo a mesma ter seus efeitos suspensos para ser convalidada por procedimento administrativo posterior, uma vez que a perda da condição de refugiado seria condição prejudicial 
para a expulsão.

O fundamento que embasou a assertiva acima foi a de que a garantia do devido processo legal seria um direito fundamental assegurado pela Constituição aos brasileiros e estrangeiros residentes no País, encontrando previsão também na Convenção de $1951^{1}$. Assim, a conclusão do processo administrativo em que seja declarada a perda da condição de refugiado deveria ser reconhecida como limitação ao poder discricionário do Executivo de expulsar um estrangeiro que ostente a condição de refugiado.

A tese levantada no voto do Ministro Humberto Martins oferece uma interpretação protetiva dos direitos dos refugiados. A Convenção de 1951 e a legislação brasileira para refugiados preveem que somente será expulso o refugiado regularmente registrado por motivos de segurança nacional ou de ordem pública ${ }^{2}$, condicionada a expulsão à decisão proferida em virtude de processo administrativo legalmente previsto em que seja assegurado o direito de defesa. O artigo 39 da Lei 9.474/97³ prevê como uma das hipóteses da perda da condição de refugiado, justamente, o exercício de atividade contrária à segurança nacional ou à ordem pública, o que nos leva à compreensão de que a decisão de expulsão de estrangeiro que detenha o status de refugiado deverá decorrer da perda dessa condição.

Convém, ademais, destacar o posicionamento do STJ acerca da análise do ato de expulsão pelo Poder Judiciário. Segundo o Relator, o Judiciário não poderia substituir a atuação da chefia do Executivo na avaliação da conveniência, necessidade, oportunidade e utilidade da expulsão, devendo limitar-se à análise do cumprimento formal dos requisitos da mesma e à inexistência de óbices à expulsão.

Isso porque o instituto da expulsão seria prerrogativa do Poder Executivo, constitucionalmente responsável pela política externa do País e pela adoção de atos que geram reflexos nas relações internacionais do Brasil com outros países, tendo em vista ser ato discricionário do Poder Executivo a análise da conveniência e da oportunidade da permanência de estrangeiro que cometa crimes em território nacional. A expulsão de estrangeiro que comete crime configuraria poder inerente à soberania do Estado.

\footnotetext{
${ }^{1}$ Convenção Relativa ao Estatuto dos Refugiados de 1951 - Art. 32: "Expulsão 2. A expulsão desse refugiado somente ocorrerá em virtude de decisão proferida conforme o processo previsto por lei. [...]”.

2 A) Convenção Relativa ao Estatuto dos Refugiados de 1951 - Art. 32: "Expulsão 1. Os Estados Contratantes não expulsarão um refugiado que se encontre regularmente no seu território senão por motivos de segurança nacional ou de ordem pública. [...]”. B) Lei 9.474/97 - Art. 36: “Não será expulso do território nacional o refugiado que esteja regularmente registrado, salvo por motivos de segurança nacional ou de ordem pública”.

3 “Art. 39. Implicará perda da condição de refugiado: [...] III - o exercício de atividades contrárias à segurança nacional ou à ordem pública”.
} 
Todavia, ainda segundo o Ministro relator, o reconhecimento da discricionariedade do ato de expulsão não corresponderia à afirmação de que tal ato afastaria apreciação e revisão pelo Poder Judiciário. Assim, estaríamos diante de uma discricionariedade regrada, uma vez que há leis e compromissos internacionais firmados pelo Estado brasileiro que impõem limites à atuação do Executivo em matéria de expulsão de estrangeiros e que, caso desobedecidos, sujeitam o ato à revisão judicial. A revisão judicial do ato de expulsão diria respeito apenas às limitações formais a que ele se sujeita, não à avaliação de seu mérito.

Podemos afirmar que o entendimento acima explicitado está em consonância com os estudos científicos sobre o instituto da expulsão realizados na vigência do Estatuto do Estrangeiro, que previa, quanto aos procedimentos de deportação, expulsão e extradição, a chamada contenciosidade limitada, que não contemplava discussão sobre o mérito da acusação, mas somente sobre os pressupostos formais previstos na legislação (MENDES, 2006, p. 16).

Entretanto, com o advento da Lei nº 13.445/17 (nova Lei de Migração), tal raciocínio merece temperamentos, porquanto a nova legislação traz de forma expressa a possibilidade de o Poder Judiciário participar dos procedimentos de retirada compulsória do território nacional ${ }^{4}$.

Ademais, não há que se falar em ampla discricionariedade do Poder Executivo na expulsão de estrangeiro, pois a legislação em apreço reduziu, consideravelmente, a discricionariedade estatal ao relacioná-la ao trânsito em julgado pela: a) prática de crimes graves sancionados pelo Estatuto de Roma, b) prática de crimes passíveis de pena privativa de liberdade e c) prática de crime comum doloso passível de pena privativa de liberdade, consideradas a gravidade e as possibilidades de ressocialização em território nacional ${ }^{5}$, bem como ao determinar expressamente que o impedimento de reingresso vinculado aos efeitos da expulsão será por prazo determinado, proporcional e nunca superior ao dobro da pena aplicada (art. 54, § 1, Lei 13.445/17) (AMARAL; COSTA, 2017, p. 222).

c) Recurso Especial no $1.174 .235 / \mathrm{PR}$ (2 $2^{\mathrm{a}}$ Turma, 2012)

O REsp $n^{0}$ 1.174.235/PR foi interposto pela União contra decisão judicial que julgou procedente ação ordinária com pedido de concessão da condição de refugiado para israelense cuja

\footnotetext{
4 “Art. 48. Nos casos de deportação ou expulsão, o chefe da unidade da Polícia Federal poderá representar perante o juízo federal, respeitados, nos procedimentos judiciais, os direitos à ampla defesa e ao devido processo legal.”

5 “Art. 54. A expulsão consiste em medida administrativa de retirada compulsória de migrante ou visitante do território nacional, conjugada com o impedimento de reingresso por prazo determinado.”
} 
requisição administrativa fora denegada pelo Conare em duas instâncias, por não ter sido constatada nenhuma das condições materiais para a concessão.

De forma bastante semelhante ao entendimento firmado no Habeas Corpus n ${ }^{\circ}$ 333.902/DF, analisado anteriormente, o Ministro Relator, Herman Benjamin, em seu voto, asseverou que o juiz, em face de pedido de concessão do refúgio, deve limitar sua cognição apenas às questões de legalidade referentes ao procedimento de análise do pedido de concessão do status de refugiado e sua revisão, jamais reapreciando os critérios de conveniência e oportunidade da decisão emanada pela autoridade governamental, por se tratar de ato discricionário da Administração.

Assim, o Poder Judiciário não deveria reapreciar os motivos e fundamentos das decisões administrativas de tal jaez, mas apenas a legalidade do procedimento em si, sob pena de se estimular o desvirtuamento do instituto do refúgio pela subversão da lógica estatuída na Convenção Relativa ao Estatuto dos Refugiados de 1951.

Segundo o entendimento do relator, o instituto do refúgio constituiria uma exceção ao exercício ordinário do controle territorial das nações, uma das mais importantes prerrogativas de um Estado soberano. Seria, na verdade, uma verdadeira concessão ad cautelam de soberania estatal, tendo em vista que o Estado Parte estaria cedendo temporariamente seu território para “ocupação de um não súdito”, sem a possibilidade de realizar juízo preliminar de conveniência ou oportunidade no momento da sua entrada por se tratar de situação delicada em que são necessárias medidas de proteção imediatas, acordadas no plano internacional. Nesse sentido, o refúgio seria uma medida protetiva de caráter precário, condicionada à permanência da situação que justificou a sua concessão.

Para ele, por ser a concessão do refúgio ato internacional de cautela excepcionalíssimo, que exigiria uma cognição exauriente da Administração no exercício de seu poder, mereceria interpretação cautelosa justamente por envolver a regra internacional do respeito aos limites territoriais dos Estados, expressão máxima de sua soberania. Por isso, apenas o Governo Federal, por meio do Ministério das Relações Exteriores, possuiria, ressalvados casos especialíssimos, a atribuição de aferir, no plano externo, a gravidade de violação a direitos humanos e decidir casos individuais sobre a matéria, incluindo a questão dos refugiados. Dessa forma, no caso em comento, ponderou que o pedido de refúgio do indivíduo era, na verdade, um requerimento com o intuito de imigrar pela via transversa, ou seja, sem submissão aos ditames do Estatuto do Estrangeiro (Lei 6.815/80).

O ministro do STJ, para reforçar seu argumento, citou trecho da ementa do julgado do STF na Extradição n ${ }^{\circ} 1008$ (2007), o qual atestava a validade da lei que reservava ao Poder Executivo, a quem incumbe, por atribuição constitucional, a competência para tomar decisões que tenham reflexos no plano das relações internacionais do Estado, o poder privativo de conceder asilo ou refúgio. 
Ao contrário do desenvolvido quanto à expulsão, o raciocínio acerca da discricionariedade estatal quanto à concessão do status de refugiado é mais delicado e controverso. Para alguns autores, o reconhecimento da condição de refugiado seria um direito subjetivo daquele que preencher as condições legalmente impostas para tanto. Nesse sentido, sob a perspectiva do Direito Administrativo, o deferimento do pedido de refúgio se caracterizaria como um ato vinculado, uma vez preenchidos os requisitos legais (ALMEIDA, 2013, p. 153).

O desafio, no entanto, é que o art. 16 (1) da Convenção de 1951 traz apenas uma garantia de que os refugiados poderão ter acesso a quaisquer recursos ou medidas judiciais existentes no Estado Parte $^{6}$. Ou seja, o tratado da ONU não estipula a espécie de assunto que poderá ser submetida aos tribunais de um Estado; isso quer dizer que o Direito Internacional não obriga os Estados a criar uma instância judicial de revisão da concessão de refúgio, muito embora determine que, todas as vezes em que os tribunais tenham competência sobre determinado assunto, os refugiados deverão ter acesso livre às cortes. Portanto, a partir de Hathaway (2005, p. 647), onde os tribunais não têm jurisdição sobre o assunto constante nas reivindicações do tipo que estão sendo propostas pelos refugiados, o art. 16 (1) não lhes oferece um remédio seguro ou evidente.

A ideia de discricionariedade do Poder Executivo no reconhecimento da condição de refugiado parece contrariar o disposto no artigo 26 da Lei 9.474/97, o qual afirma ser ato declaratório a decisão do Comitê Nacional para Refugiados. Igualmente desconsidera os esclarecimentos do próprio Ministério da Justiça, que, em seu sítio eletrônico, afirma que, ao contrário do asilo, uma das características do refúgio é justamente a de possuir efeito declaratório ${ }^{7}$.

Por outro lado, a Corte Interamericana de Direitos Humanos (Corte IDH) ${ }^{8}$ parece adotar uma posição intermediária, mais próxima à esposada pelo STJ. Ao menos no que diz respeito à sua competência contenciosa e sua posição institucional, a Corte IDH afastou a possibilidade de um tribunal internacional reanalisar a decisão administrativa tomada pelos órgãos internos de um Estado quanto à concessão ou denegação do pedido de refúgio (§§ 170 e 192). Contudo, reconheceu um direito humano à avaliação criteriosa e baseada no devido processo legal dos pedidos, assim que formulados (§ 196).

Da decisão que não concede o refúgio, bem como da que o concede ilegalmente, cabe ação judicial, ao menos no caso brasileiro, para a defesa da legalidade e da ordem jurídica (VELLOSO,

\footnotetext{
${ }^{6}$ Qualquer refugiado terá, no território dos Estados Contratantes, livre e fácil acesso aos tribunais.

${ }^{7}$ Disponível em: http://bit.ly/2Irc5gp. “Característcas do refúgio [...] g) Efeito declaratório; [...]”.

${ }^{8}$ Corte IDH. Caso familia Pacheco Tineo Vs. Bolivia. Excepciones Preliminares, Fondo, Reparaciones y Costas. Sentencia de 25 de noviembre de 2013.
} 
2009, p. 16), tendo em vista que incumbe ao Poder Judiciário corrigir eventual ilegalidade, inconstitucionalidade ou abuso de ato administrativo, em observância ao princípio constitucional da inafastabilidade do controle judicial de lesão ou ameaça a direito (VELLOSO, 2009, p. 17).

André Ramos (2017, p. 300-301), por exemplo, entende ser possível a revisão judicial da análise fática feita pelo Conare para fins de concessão de refúgio, inclusive para que decisões concessivas caracterizadas como abusivas possam ser controladas. Para aquele autor, mesmo o reflexo negativo da decisão nas relações internacionais do País não seria motivo suficiente para retirar do Judiciário a competência para realizar o controle do ato administrativo de concessão de refúgio. Contudo, pondera que, nas hipóteses de questionamentos judiciais de concessões, o ônus argumentativo do STF será maior, tendo em vista a incidência do princípio do non-refoulement.

Nesse sentido, o Supremo Tribunal Federal, na Extradição $n^{\circ} 1085^{9}$, julgado anterior ao caso do STJ em análise e que, ainda que não expressamente, revogou o precedente da Extradição nº 1008 , assentou a possibilidade de o ato de concessão de refúgio por parte do Ministro da Justiça ser objeto de anulação pelo STF no caso de não existir correspondência entre os motivos declarados para o refúgio e o suporte fático da hipótese legal, ou seja, no caso de ter sido concedido ilegalmente.

Muito embora o ministro relator do caso, Cezar Peluso, tenha afirmado estar no campo da fiscalização da legalidade de ato administrativo vinculado, sugere que a análise administrativa dos fatos às hipóteses legais pode ser aferida pelo STF, especialmente quando a legalidade do ato administrativo determinar a exclusão da análise de um caso já submetido à cognição da Corte, como a extradição em análise ${ }^{10}$. Ora, se o Judiciário é competente para analisar, amplamente, o ato de concessão, com certeza poderá fiscalizar o ato de denegação, porquanto estará imbuído da mesma avaliação administrativa dos fatos apresentados pelo requerente.

Parece-nos que a intepretação do STJ, ainda que não contrária aos preceitos da Corte IDH e do Direito Internacional dos Refugiados, contraria a natureza do ato administrativo concessivo ou denegatório do status de refúgio tal como estipulado pela legislação nacional e pela jurisprudência do STF. Dessa forma, nos casos em que é indeferido o pedido de refúgio no âmbito administrativo, é perfeitamente possível que o Poder Judiciário brasileiro reconheça tal condição em sede de ação judicial sem que haja qualquer tipo de afronta ao princípio da independência dos Poderes

\footnotetext{
${ }^{9}$ Ext 1085, Rel. Min. Cezar Peluso. Tribunal Pleno, DJe 16/04/2010.

${ }^{10}$ Lewandowski, o Ministro seguinte a votar, resume o ponto analisado: "Em outras palavras, o Judiciário pode, se instado a tal, verificar se estão ou não presentes, a justificar o ato de concessão de refúgio, os elementos subjetivos e objetivos previstos na Lei 9474/97 e na Convenção de 1951, dentre as quais, o temor e o fundado receio de perseguição por motivos de raça, religião, nacionalidade, grupo social ou opinião política, bem assim as hipóteses que elidem o princípio da nãodevolução.”
} 
(ALMEIDA, 2013, p. 153), muito embora a revisão judicial do mérito não seja uma obrigação internacional decorrente de um direito humano.

d) Habeas Corpus n ${ }^{\circ}$ 98.735/DF (1ª Seção, 2008)

Sob enfoque diverso, mas ainda sobre a expulsão de refugiado, temos o Habeas Corpus $\mathrm{n}^{\circ}$ 98.753/DF, impetrado contra ato do Ministro de Estado da Justiça que decretou a expulsão do paciente, estrangeiro refugiado, em razão de sua condenação pela prática de crimes relacionados ao tráfico de entorpecentes. Neste acórdão, no qual o princípio da unidade familiar fora reconhecido pelo Superior Tribunal de Justiça, o impetrante sustentou a impossibilidade de sua expulsão pelo fato de possuir filho brasileiro, nascido antes da condenação pelo fato delituoso, o qual dependeria economicamente do paciente para sobreviver.

A despeito de ter sido denegada a ordem em virtude da inexistência de prova pré-constituída capaz de evidenciar as alegações expostas no writ, a Ministra Denise Arruda, relatora, ressaltou a orientação jurisprudencial consolidada do STJ no sentido da impossibilidade de expulsão de estrangeiro que tenha filho brasileiro sob sua guarda e que dele dependa economicamente. Tal entendimento encontra fundamento na necessidade de proteção dos interesses do menor, sejam estes econômicos ou afetivos.

À época do julgado encontrava-se em vigor a Lei n ${ }^{\circ}$ 6.815/80 (Estatuto do Estrangeiro), que em seu artigo 75, II, b, previa que não se procederia à expulsão de estrangeiro que tivesse filho brasileiro que comprovadamente estivesse sob sua guarda e dele dependesse economicamente. É importante ressaltar que a Lei 13.445/17, que revogou o Estatuto do Estrangeiro, manteve a disposição anteriormente citada e ainda estendeu a impossibilidade de expulsão para aquele que tiver filho brasileiro sob dependência socioafetiva ou tiver qualquer outra pessoa brasileira sob sua tutela, em importante inovação legislativa ${ }^{11}$.

Considerou a relatora que as informações prestadas pelo paciente, tanto no seu pedido de refúgio, quanto no HC julgado pelo STJ eram confusas e insuficientes para indicar a paternidade da criança, sua nacionalidade, sua dependência material e se havia convivência familiar. As autoridades nacionais afirmaram que o autor do HC prestara, propositadamente, informações falsas ao Conare durante todo o processo de refúgio. Os votos vencidos, encabeçados pelo Ministro Teori Zavascki, concediam a ordem, exatamente por entenderem os princípios relacionados à proteção dos interesses

\footnotetext{
11 “Art. 55. Não se procederá à expulsão quando: [...] II - o expulsando: a) tiver filho brasileiro que esteja sob sua guarda ou dependência econômica ou socioafetiva ou tiver pessoa brasileira sob sua tutela.”
} 
das crianças como superiores às determinações relacionadas à expulsão.

Nesse sentido, todas as decisões que envolvam direitos da criança, sejam elas participantes ou não do processo, exigem do Estado um maior escrutínio no que diz respeito às garantias judiciais e processuais (arts. 8 e 25 da CADH) ${ }^{12}$. Para a Corte IDH, há uma relação intrínseca existente entre o direito à proteção da família e os direitos das crianças, devendo o Estado dispor e executar medidas de proteção às mesmas, bem como favorecer o fortalecimento do núcleo familiar. Dessa forma, mesmo as separações juridicamente permitidas da criança de sua família só podem prosseguir se forem devidamente justificadas com base no melhor interesse da criança, forem excepcionais e, na medida do possível, temporárias ${ }^{13}$.

O Alto Comissariado das Nações Unidas para os Refugiados (ACNUR) (2013, p. 39) considera natural que haja confusão, informações inconsistentes ou falta de provas sobre a história prestada pelo refugiado. Exatamente por essa razão, aos requerentes de refúgio é conferido o benefício da dúvida, a não ser que suas declarações contrariem fatos geralmente conhecidos (§§ 203204). No caso, muito embora houvesse dúvidas quanto ao nome do refugiado, o qual era incompatível com o nome do pai na certidão de nascimento da criança (ele alegava que o erro material teria sido do Conare), a Corte não levou em conta o benefício da dúvida em favor do paciente.

No caso analisado, pensamos que o STJ deveria ter dado maior atenção, na linha do exposto pelo Ministro Zavascki, ao risco de violações aos direitos da criança e do adolescente. Não, necessariamente, no sentido de uma concessão automática do HC, mas a relatora deveria, no caso de dúvida quanto à existência ou não de crianças envolvidas, ter aplicado a interpretação reforçada das garantias judiciais estipulada pela Corte IDH. Como contraposição, não podemos deixar de destacar que a via eleita (HC) talvez dificultasse tal requerimento de dilação probatória.

e) Mandados de Segurança $n^{0} 17.611 / D F\left(1^{\text {a }}\right.$ Seção, 2013), $n^{0}$ 12.510/DF ( $1^{\text {a }}$ Seção, 2007), $n^{\circ}$ 11.417/DF ( $1^{a}$ Seção, 2007) e ${ }^{0} 13.383 / D F ~\left(1^{a}\right.$ Seção, 2008) e Agravo Regimental no Mandado de Segurança $\mathrm{n}^{\circ}$ 17.612/DF (1 $1^{\text {a }}$ Seção, 2011)

Por fim, os últimos acórdãos a serem analisados são os Mandados de Segurança $n^{\circ}$ 17.611/DF, $\mathrm{n}^{\circ}$ 12.510/DF, $\mathrm{n}^{\circ}$ 11.417/DF e $\mathrm{n}^{\circ}$ 13.383/DF e o Agravo Regimental no Mandado de Segurança $n^{0}$ 17.612/DF, julgados pela Primeira Seção do STJ. Todos foram impetrados contra ato

\footnotetext{
12 Corte IDH. Caso familia Pacheco Tineo Vs. Bolivia. Excepciones Preliminares, Fondo, Reparaciones y Costas. Sentencia de 25 de noviembre de 2013, § 220.

$13 \S 226$.
} 
do Ministro de Estado da Justiça que indeferiu os pedidos de concessão do status de refugiado feitos pelos impetrantes.

O Mandado de Segurança $n^{\circ} 17.611$ (2013) foi proposto por pessoa que teve seu pedido de refúgio indeferido. Em suas alegações, sustentou violações ao devido processo legal, tendo em vista que o Ministro de Estado da Justiça compunha o Conare na data do indeferimento e julgara, posteriormente, o recurso interposto.

A segurança foi denegada sob a assertiva de que, em razão da natureza colegiada da decisão proferida pelo Comitê Nacional para Refugiados e do órgão em si, não haveria ilegalidade no fato de o Ministro da Justiça ter negado provimento ao recurso interposto contra decisão proferida na época em que presidia o Conare, tendo em vista não ter exercido voto decisivo na ocasião, ante a ausência de empate. Ademais, reforçou o relator, não havia qualquer impedimento na participação do ministro de Estado no julgamento do recurso, com base na Lei do Procedimento Administrativo (Lei 9.784/99). Em função da necessidade de dilação probatória e da via eleita para questionar o ato administrativo, o ministro considerou inviável o reexame da alegação de violações de direitos humanos motivadora da migração.

Já o Mandado de Segurança $n^{\circ} 12.510$ (2007) foi denegado por não ter havido, no entendimento dos ministros do STJ, ilegalidade na decisão do Ministro da Justiça que indeferiu o pedido de concessão do status de refugiado, e, assim, não ter ocorrido violação de direito líquido e certo do impetrante, já que se tratava de brasileiro naturalizado, não se aplicando as condições de admissibilidade previstas na Lei 9.784/99.

A ministra relatora considerou que não houve violação dos princípios constitucionais do contraditório, do devido processo legal e da ampla defesa, porquanto foi dada ciência ao pleiteante de todos os atos emanados das autoridades administrativas, bem como a oportunidade de recorrer da decisão proferida pelo Conare. A decisão de indeferimento do Conare estava baseada em um dado fundado: o requerente era brasileiro naturalizado, justificando a desnecessidade de outros atos relativos ao processo de concessão (art. $3^{\circ}$, II da Lei 9.474/9714).

Quanto ao Mandado de Segurança n 11.417 (2007), temos que este foi denegado por terem os ministros entendido que o ato administrativo de indeferimento da concessão de refúgio encontravase absolutamente revestido de todos os requisitos legais exigidos para que fosse tido como perfeito e

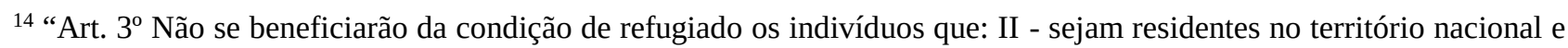
tenham direitos e obrigações relacionados com condição de nacional brasileiro.”
} 
acabado: competência, finalidade, motivo e objeto ${ }^{15}$.

Segundo o voto do Ministro Relator, José Delgado, as formalidades legais teriam sido respeitadas no decorrer do processo administrativo, já que o impetrante teve acesso aos procedimentos legais e havia sido oportunamente cientificado do indeferimento do pedido e da possibilidade de recorrer da decisão. Assim, a autoridade coatora não teria praticado ato, comissivo ou omissivo, configurador de lesão ao direito subjetivo líquido e certo do impetrante. Muito embora não tenha debatido diretamente em seu voto, é importante destacar que o requerente fez o pedido de refúgio tão logo fora deferida sua extradição por parte da Corte Suprema dinamarquesa, tendo o Conare justificado sua decisão com base no art. $3^{\circ}$, III, da Lei 9.474/9716.

Nesse mesmo sentido temos o Mandado de Segurança $n^{0}$ 13.383/DF (2008), impetrado também contra ato do Ministro da Justiça que indeferiu a solicitação de reconhecimento da condição de refugiado do impetrante. A tese que sustentou a denegação do referido mandado de segurança confirma o posicionamento do STJ, acima explicitado, como veremos a seguir.

O Ministro Carlos Fernando Mathias asseverou em seu voto que o writ merecia ser denegado pelo fato de as formalidades legais terem sido respeitadas no decorrer do processo administrativo de concessão do refúgio, no qual o impetrante teve amplo acesso aos procedimentos legais, bem como foi cientificado do indeferimento do pedido e da oportunidade de recorrer da decisão. Sendo assim, não teria sido verificada a ocorrência de vícios no procedimento administrativo ou cerceamento de defesa.

Segundo o ministro, o ato de indeferimento da concessão de refúgio estava absolutamente revestido de todos os requisitos legais exigidos para que fosse tido como perfeito e acabado: competência, finalidade, motivo e objeto. Assim, inexistente ato ilegal, comissivo ou omissivo, por parte da autoridade coatora, configurador de lesão ao direito subjetivo líquido e certo do impetrante.

A decisão, diferentemente dos mandados de segurança há pouco analisados, adentrou no mérito da não concessão do refúgio. O ministro relator considerou, após analisar os relatos prestados pela Polícia Federal, Ministério Público Federal e Conare, que o requerente não se enquadrava em nenhuma hipótese legal de refúgio, porquanto as ameaças por ele sofridas haviam ocorrido há muitos

\footnotetext{
15 Não podemos deixar de destacar que Pannunzio (2014, p. 166) realiza leitura diversa da orientação do STJ nos MS 11.417 e 12.510, porquanto considera que, neles, aquela corte teria se posicionado no sentido de considerar legítima a revisão judicial do mérito da concessão da condição de refugiado. Contudo, não nos parece correta tal interpretação das decisões, uma vez que em nenhuma delas a corte afirma tal competência de forma expressa, e Herman Benjamin, no Resp 1.174.235 (2012), utiliza as mesmas duas decisões para ratificar que não se deve reapreciar os motivos e fundamentos das decisões administrativas de tal jaez, mas apenas a legalidade do procedimento.

16 “Art. $3^{\circ}$ Não se beneficiarão da condição de refugiado os indivíduos que: II - tenham cometido crime contra a paz, crime de guerra, crime contra a humanidade, crime hediondo, participado de atos terroristas ou tráfico de drogas.”
} 
anos e o motivo de sua vinda para o Brasil teria sido a busca por melhores condições econômicas de vida. É importante ressaltar, portanto, que, ainda que para denegar a segurança, o STJ adentrou no mérito do ato administrativo, antes da decisão do STF na Extradição n ${ }^{0} 1085$ (2010).

Por fim, temos o Agravo Regimental no Mandado de Segurança n ${ }^{0}$ 17.612/DF (2011), que, apesar de se tratar de decisão meramente processual que negou provimento ao agravo e confirmou a denegação da segurança por ausência de prova pré-constituída do ato coator, demonstra também o entendimento do STJ acerca da análise judicial da concessão da condição de refugiado.

De acordo com a manifestação do relator, Ministro Mauro Campbell Marques, a concessão da condição de refugiado, apesar de se tratar de manifestação da soberania brasileira, pode ser sindicável no Judiciário na qualidade de ato administrativo. Assim, o pedido de análise da legalidade do indeferimento do pedido de concessão do status de refugiado pelo Judiciário seria pedido juridicamente possível.

Pode-se perceber, nos últimos julgados acima, que o processo administrativo que culminou no indeferimento do pedido de concessão da condição de refugiado, bem como o próprio ato de indeferimento passaram, em sua maioria, por análises superficiais do princípio da legalidade, sem haver um mais aprofundado exame da questão de terem, ou não, os impetrantes preenchido os critérios legais para a concessão do status de refugiado.

É bem verdade que o mandado de segurança é uma ação de natureza sumária, indicada para a proteção de direito líquido e certo ameaçado ou violado por ato ilegal ou abusivo de autoridade, devendo tal direito ser comprovado de plano, não sendo permitida dilação probatória. Porém, a ausência de uma análise aprofundada dos critérios legais do refúgio parece demonstrar que o STJ encara sua concessão como um ato administrativo cuja discricionariedade é um atributo, não se preocupando em reavaliar os critérios de indeferimento ou concessão.

\section{f) Habeas Corpus $n^{0} 36.033 / \mathrm{DF}\left(1^{\mathrm{a}}\right.$ Seção, 2005)}

O último acórdão a ser analisado é o Habeas Corpus nº 36.033/ DF, caso em que o impetrante visava a suspensão do ato que denegou seu pedido de concessão do status de refugiado para que pudesse permanecer no território brasileiro.

O ministro relator denegou o Habeas Corpus “conforme as informações colacionadas pela autoridade impetrada”, que afirmou que o impetrante jamais foi perseguido por razões de ordem política, tendo fundado seu pedido de refúgio em sua recusa em prestar o serviço militar, bem como 
que a região da qual era egresso, Huila, não era considerada localidade de risco, não havendo fundado temor de perseguição por motivos de raça, religião, nacionalidade, grupo social ou opiniões políticas.

Em seu voto, o ministro apenas reiterou o exposto pelas autoridades brasileiras, reforçando suas leituras sobre o requerimento. A decisão parece demonstrar alguns elementos a serem explorados: 1) o STJ tende a seguir as decisões de mérito expedidas pelas autoridades brasileiras sem maiores questionamentos, tendo em vista que, para reforçar o indeferimento, não contrasta as informações trazidas pelo requerente, mas apenas transcreve manifestações dos agentes estatais e 2) as vias processuais acionadas podem influenciar o juízo do STJ, tendo em vista que são apresentadas por meio de procedimento de cognição limitada, seja o REsp, MS e HC.

\subsection{DECISÕES MONOCRÁTICAS DE MINISTROS QUE COMPÕEM O STJ}

Quanto às decisões monocráticas, o Recurso Especial n ${ }^{\circ}$ 1.163.011/RS (2017) trouxe à tona importante entendimento que fortalece a proteção dos direitos dos refugiados no Brasil. O referido REsp foi interposto pela União contra acórdão do Tribunal Regional Federal da 4 a Região que decidiu ser o Ministério Público parte legítima para figurar como substituto processual de estrangeiros cubanos em ação com vistas à concessão do status de refugiado, sob o fundamento de que o Parquet possuía legitimidade para a defesa dos direitos individuais indisponíveis, mesmo quando a ação visava a tutela de pessoa individualmente considerada.

A União alegou a ausência de previsão legal para a substituição processual e a ausência de prova de que os interessados tivessem provocado o Ministério Público para tanto. Em seu voto, o Ministro Sérgio Kukina ressaltou que seria firme a jurisprudência do STJ no sentido de considerar que o Ministério Público possui legitimidade para a defesa de direitos individuais indisponíveis como substituto processual em situações que envolvam a possível violação de direitos humanos de estrangeiros, os quais correm risco de sofrer represálias pelo governo de seu país de origem.

A decisão em apreço pode ser analisada sob dois aspectos. Primeiramente, merece destaque por ter ressaltado que a pretensão à concessão do refúgio se trata de direito individual indisponível, tal qual o direito à vida, os direitos de personalidade e os referentes ao estado e capacidade da pessoa e, portanto, seus titulares não têm qualquer poder de disposição sobre ele - posicionamento alinhado com as decisões da Corte IDH. Em segundo lugar, a referida decisão se amolda à expressa previsão constitucional contida no artigo 127 da Carta Magna, que legitima o Ministério Público para atuar na defesa dos direitos individuais indisponíveis, nas hipóteses em que os órgãos estatais não respeitem tais direitos, cuja integridade o Poder Público deve velar, frustrando-lhes a eficácia jurídico-social. 
É importante frisar que a atuação do Parquet deve abranger não só a garantia do direito ao refúgio, mas também a salvaguarda do direito de não retorno. Isso porque o princípio da não devolução proíbe a deportação de estrangeiro (seja aquele que busca refúgio ou asilo) para fronteira de território em que sua vida ou liberdade esteja ameaçada; preceitua, ademais, que o ingresso irregular no território nacional não constitui impedimento para a solicitação do refúgio às autoridades competentes e ainda garante que mesmo no caso de ser denegada a solicitação do refúgio, fica proibida a transferência do solicitante para seu país de nacionalidade ou de residência habitual enquanto permanecerem as circunstâncias que põem em risco sua vida, integridade física e liberdade.

Ademais, ressalte-se que são diversas as oportunidades de cooperação, na área de proteção aos refugiados, em que o Ministério Público pode atuar, já que, além de acusador, o órgão ministerial é fiscal da ordem jurídica e, dessa forma, pode desempenhar importante papel na aplicação da legislação sobre o refúgio. Apesar de sua relevância, tal papel não pode se resumir ao oferecimento de pareceres pautados nos princípios do Direito Internacional dos Refugiados, mas também deve compreender a atuação proativa da Instituição na acusação em casos de violação dos direitos dos refugiados e o apoio financeiro a projetos em prol desta população (MORAES, 2014, p. 177-178).

Ainda sobre a expulsão de estrangeiro, temos o Habeas Corpus n 412.840 (2017), impetrado pela Defensoria Pública da União em face de ato do Ministro da Justiça, que determinou a expulsão do paciente, que cumpria pena por crime relacionado ao tráfico de drogas, após o cumprimento da pena a que estava sujeito ou a eventual liberação pelo Poder Judiciário. O impetrante sustentava que a portaria ministerial em apreço seria ilegal em virtude de existir pedido de refúgio pendente de análise formalizado pelo paciente perante o Conare.

O ponto nodal de discussão no Habeas Corpus n 412.840 refere-se à necessidade ou não de suspensão do procedimento de expatriação até a superveniência de apreciação do pedido de refúgio pelo Comitê Nacional para Refugiados.

O ministro relator argumentou que a Lei $n^{\circ}$ 9.474/97, ao tratar do instituto da expulsão, estabelece que o refugiado regularmente registrado pode ser expulso do território nacional por motivos de segurança nacional ou de ordem pública, nos termos dos artigos 36 e $37^{17}$.

Por ter vislumbrado que o impetrante não obteve êxito em comprovar a existência de qualquer das causas de exclusão da expulsabilidade contidas no artigo 75, I e II, do antigo Estatuto

\footnotetext{
17 “Art. 36. Não será expulso do território nacional o refugiado que esteja regularmente registrado, salvo por motivos de segurança nacional ou de ordem pública.” “Art. 37. A expulsão de refugiado do território nacional não resultará em sua retirada para país onde sua vida, liberdade ou integridade física possam estar em risco, e apenas será efetivada quando da certeza de sua admissão em país onde não haja riscos de perseguição.”
} 
do Estrangeiro ${ }^{18}$, vigente à época da decisão (presença de cônjuge brasileiro do qual o estrangeiro não esteja divorciado ou separado, de fato ou de direito, e desde que o casamento tenha sido celebrado há mais de cinco anos ou a presença de filho brasileiro que, comprovadamente, esteja sobre sua guarda e dele dependa economicamente), o ministro denegou o writ.

No entendimento do Ministro Sérgio Kukani, a formalização do pedido de refúgio, por si só, não teria o condão de suspender a expulsão de estrangeiro condenado por tráfico internacional de entorpecentes, e, desse modo, não haveria ilegalidade ou abuso de poder na portaria do Ministro de Estado da Justiça.

A decisão não parece seguir os padrões legais internos e internacionais. Isso porque o mero pedido de refúgio suspende todo e qualquer procedimento de saída compulsória, seja deportação, expulsão ou extradição (DINIZ; PEREIRA, 2014, p. 171). Esse é, inclusive, o posicionamento do Ministério da Justiça, que em seu sítio eletrônico afirma que, enquanto tramita um processo de refúgio, os pedidos de expulsão ou extradição ficam suspensos ${ }^{19}$.

Assim entende, igualmente, o STF, que sustentou, na Extradição $n^{\circ} 1424 / \mathrm{DF}^{20}$, a tese de que nem mesmo eventual deferimento de pedido de extradição obsta a suspensão do processo em face de pedido de refúgio, nos termos do artigo 34 da Lei $n^{\circ} 9.474 / 97^{21}$, desde que formulado antes do trânsito em julgado da extradição.

Por sua vez, o Habeas Corpus $n^{\circ} 115.183 / \mathrm{DF}$ (2011) foi denegado por manifesta improcedência do pedido. Nele, o impetrante alegava a nulidade do procedimento da concessão de refúgio, que ao final indeferiu sua pretensão ao reconhecimento da condição de refugiado, por inobservância aos princípios da ampla defesa e do devido processo legal.

A decisão teve por fundamento o fato de a Lei n ${ }^{\circ}$ 9.474/97 não prever a presença de advogado em nenhuma das etapas do processo de reconhecimento da condição de refugiado. Segundo a Ministra Relatora, Denise Arruda, a Constituição Federal garante aos litigantes, em processo judicial ou administrativo, e aos acusados em geral, o contraditório e a ampla defesa, com os meios e recursos a ela inerentes. Todavia, a extensão da garantia constitucional do contraditório aos procedimentos

\footnotetext{
${ }^{18}$ Hoje artigo 55 da Lei 13. 445/17, que versa: “Art. 55. Não se procederá à expulsão quando: I - a medida configurar extradição inadmitida pela legislação brasileira; II - o expulsando: a) tiver filho brasileiro que esteja sob sua guarda ou dependência econômica ou socioafetiva ou tiver pessoa brasileira sob sua tutela; b) tiver cônjuge ou companheiro residente no Brasil, sem discriminação alguma, reconhecido judicial ou legalmente.”

${ }^{19}$ Disponível em: http://bit.ly/2V6rVD9.

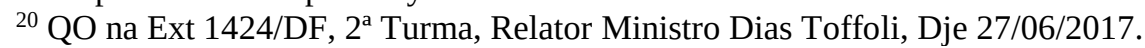

21 “Art. 34. A solicitação de refúgio suspenderá, até decisão definitiva, qualquer processo de extradição pendente, em fase administrativa ou judicial, baseado nos fatos que fundamentaram a concessão de refúgio.”
} 
administrativos não teria o significado de subordinar a estas toda a normatividade referente aos feitos judiciais, para os quais é indispensável a atuação do advogado.

Nesse sentido, uma vez dada a oportunidade ao impetrante de se defender e de oferecer pedido de reconsideração da decisão que indeferiu sua pretensão, descabível seria falar em ofensa aos princípios da ampla defesa e do contraditório, pelo fato de ser considerado dispensável, no processo administrativo, a presença de advogado, cuja atuação seria obrigatória somente no âmbito judicial.

Trata-se de decisão prolatada à época das discussões jurisprudenciais sobre a dispensabilidade ou não de defesa técnica em processo administrativo disciplinar, que levaram à aprovação, pelo Supremo Tribunal Federal, da Súmula Vinculante $\mathrm{n}^{0} 5^{22}$. Hoje é pacífico o entendimento de não ser obrigatória a intervenção de advogado em quaisquer processos e procedimentos administrativos.

Entretanto, e sem adentrar a questão acerca da via processual, o impetrante sustentou que fora interrogado sem que a sua defesa, impedida de entrar no recinto, estivesse presente e que, por não dominar a língua portuguesa, deixou de esclarecer, ou não foi indagado, sobre questões cruciais, tais como a forma e o detalhamento da tortura que sofreu quando preso na Coreia.

Pensamos que os requerimentos feitos pelo solicitante de refúgio que teve sua extradição deferida, como no caso em comento, deverão atrair as determinações da Corte IDH na OC 16/99, especialmente por conta da prisão obrigatória decorrente do processamento dos pedidos de extradição, tal como previsto na lei anterior ${ }^{23}$ (Lei 6.815/80). De acordo com a Corte IDH, o direito à assistência consular para estrangeiros detidos, sob qualquer justificava, é um Direito Humano, como desdobramento do devido processo legal. Dessa forma, o pedido de indeferimento do refúgio pode ter sido influenciado pela falta de informações prestadas às autoridades administrativas decorrente do não domínio do vernáculo por parte do requerente.

O ACNUR não dispõe de poderes para assistir de forma direta os refugiados, individualmente, na reivindicação de seus direitos no âmbito interno, tal como no presente caso. Trata-se de decisão consciente tomada pela Assembleia Geral no mandato daquela agência (HATHAWAY, 2005, p. 634). No entanto, da interpretação do art. 25 (1) 24 da Convenção, devemos

\footnotetext{
22 “A falta de defesa técnica por advogado no processo administrativo disciplinar não ofende a Constituição.”

23 “Art. 84. Efetivada a prisão do extraditando (artigo 81), o pedido será encaminhado ao Supremo Tribunal Federal. Parágrafo único. A prisão perdurará até o julgamento final do Supremo Tribunal Federal, não sendo admitidas a liberdade vigiada, a prisão domiciliar, nem a prisão albergue.” A prisão cautelar (que agora poderá ser domiciliar) permanece na nova Lei de Migrações, muito embora agora entre em regime de urgência, excecionalidade e, caso não haja apresentação do pedido de extradição, o requerido será posto em liberdade (art. 84, 85 e 89).

24 "Quando o exercício de um direito por um refugiado normalmente exigir a assistência de autoridades estrangeiras às quais não pode recorrer, os Estados Contratantes em cujo território reside providenciarão para que essa assistência lhe seja dada, quer pelas suas próprias autoridades, quer por uma autoridade internacional.”
} 
extrair que os Estados têm uma responsabilidade afirmativa de estabelecer um mecanismo pelo qual os refugiados possam se beneficiar, na prática, dos seus direitos (HATHAWAY, 2005, p. 636). Os Estados, portanto, estão obrigados a oferecer assistência administrativa aos refugiados que não puderem obtê-la por canais consulares regulares (UN Doc.E/AC.32/SR.19, Feb. 1, 1950, at 4).

Ainda que não tenha ficado demonstrado de forma clara no acórdão, o STF parece considerar a assistência consular do extraditando uma obrigatoriedade, desde o momento de sua detenção nas dependências da Polícia Federal. Seguindo a interpretação do Relator, Joaquim Barbosa, o Ministro Celso de Mello afirmou em seu voto na Extradição ${ }^{0} 1.126^{25}$ que a negativa de notificação consular implicaria violação do devido processo legal e que aquela deve ser feita tão logo seja realizada a prisão do estrangeiro (antes, portanto, de qualquer manifestação perante as autoridades nacionais). O Ministro Marco Aurélio, em seguida, confessou que não teria verificado a comprovação da formalidade em processos de extradição anteriores que julgara; assistência, porém, que considerou ser essencial à validade da constrição.

Dessa forma, estando pendente o pedido de refúgio de extraditando privado de liberdade, parece-nos que um maior escrutínio deve ser empregado nessas hipóteses, em função da condição de pessoa sob a tutela do Estado, devendo ser assegurado ao estrangeiro, no mínimo, o direito de assistência consular previsto no art. 36, 1, b, da Convenção de Viena sobre Relações Consulares, tido como Direito Humano pela Corte IDH (OC 16/99) e Direito Fundamental pelo STF (Ext 1126), uma vez que a presença de advogado não seria obrigatória.

\section{ANÁlise GLOBAL DOS CASOS NO STJ: DEFERÊNCIA AO EXECUTIVO E INCOERENCIAS INTERPRETATIVAS}

Podemos categorizar as decisões judiciais analisadas no capítulo anterior em três grupos: 1) aquelas que apresentam uma leitura mais protetiva do direito dos refugiados e estão em consonância com seu regramento internacional e/ou com a jurisprudência do STF; 2) as que estão parcialmente consonantes ao direito internacional e/ou constitucional e 3) as que aparentam construir um padrão não consentâneo à proteção internacional e/ou constitucional.

Identificamos como integrantes do primeiro grupo o REsp $n^{\circ} 1.475 .580 / \mathrm{RJ}$ (4 $4^{\mathrm{a}}$ Turma, 2017), o REsp n ${ }^{\circ}$ 1.163.011/RS (Decisão Monocrática, 2017) e o HC nº 98.735/DF (1ª Seção, 2008). Tais decisões apresentam uma leitura mais protetiva do direito dos refugiados e estão em consonância com seu regramento internacional e/ou com a jurisprudência do STF, conforme já analisado, por

\footnotetext{
${ }^{25}$ Tribunal Pleno, Rel. Joaquim Barbosa, DJe 11/12/2009.
} 
terem, respectivamente, a) garantido aos refugiados e aos estrangeiros em geral o exercício de seus direitos fundamentais no Brasil mediante, tão somente, a expedição da documentação própria de estrangeiro; b) atestado a legitimidade do Ministério Público para figurar como substituto processual em ação com vistas à concessão do status de refugiado e, por fim, c) asseverado a impossibilidade de expulsão de estrangeiro que tenha filho brasileiro sob sua guarda e que dele dependa economicamente.

No grupo das decisões parcialmente harmônicas com o Direito Internacional e/ou Constitucional temos o HC $n^{0}$ 333.902/DF (1 $1^{\text {a }}$ Seção, 2015) e o HC $n^{0}$ 36.033/DF (1 $1^{\text {a }}$ Seção, 2005). As referidas decisões estão sendo categorizadas dessa forma pelo fato de o STJ, na primeira delas, a) ter limitado a participação do Judiciário à análise formal dos procedimentos de retirada compulsória do território nacional, apesar de ter firmado entendimento no sentido de considerar nula portaria de expulsão editada contra refugiado antes de instaurado regular processo administrativo de perda de refúgio; e, na segunda delas, b) pelo fato de o STJ não ter feito nenhuma menção à necessidade de se analisar, no processo administrativo para a concessão do status de refugiado, o contexto real da situação vivenciada pelo solicitante do refúgio, não obstante a decisão administrativa ter sido, aparentemente, acertada.

Finalmente, o terceiro grupo aparenta construir uma interpretação não consentânea aos padrões internacionais e/ou constitucionais e é composto pelas seguintes decisões: REsp $\mathrm{n}^{\circ}$

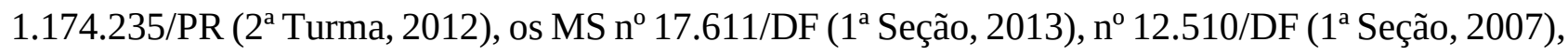

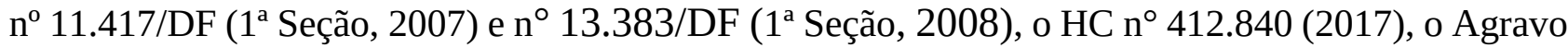

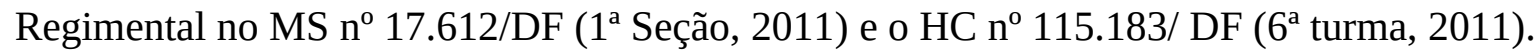

É interessante ressaltar que, dentre as decisões citadas anteriormente, somente uma não versa sobre o indeferimento do pedido de concessão do refúgio, qual seja, o Habeas Corpus $n^{\circ} 412.840$, na qual o STJ considerou que a formalização do pedido de refúgio, por si só, não tem o condão de suspender a expulsão de estrangeiro, em desacordo com o regime para refugiados, como demonstrado no tópico 2.2.

As demais decisões parecem contrariar o direito constitucional dos refugiados porque, ou consideram que a concessão do status de refugiado é ato discricionário do Estado ou, a partir dessa premissa, detêm-se à análise da legalidade do ato de denegação do refúgio, desconsiderando a possibilidade de controle material de tal ato pelo Poder Judiciário, mesmo após a manifestação do STF na Extradição nº 1085 (2010). 
Podemos afirmar que o que levou o Superior Tribunal de Justiça a proferir tais decisões foi, justamente, a crença no entendimento de ser de competência do Poder Executivo decidir, definitiva e discricionariamente, a questão dos refugiados, e, desse modo, ser indevida a ingerência do Poder Judiciário no tema. Tal compreensão parece confirmar, quanto ao STJ, a hipótese de Jubilut (2011) sobre a intangibilidade, no mérito, da concessão administrativa do refúgio. O fundamento da discricionariedade seria a competência do Executivo de atuar no campo das relações internacionais e por tratar de tema sensível à soberania do Estado brasileiro.

A intangibilidade judicial do mérito administrativo não contraria o Direito Internacional dos Direitos Humanos, porém não se coaduna com a interpretação constitucional sobre o tema, a demonstrar a dissonância entre o posicionamento do STF e do STJ sobre o assunto. Voltaremos a esse ponto mais adiante.

Percebe-se que, de modo geral, a jurisprudência do STJ versa sobre dois tipos de casos sobre a temática referente ao direito dos refugiados: aqueles em que se discute a denegação do pedido administrativo de concessão do status de refugiado e os que tratam sobre a expulsão de refugiado ou solicitante de refúgio. Portanto, das cinco categorias expostas na introdução, duas delas perfazem a maior parte dos casos de judicialização do refúgio, quais sejam: a) casos sobre o resultado do processo de solicitação de refúgio, nos quais se debatem as questões formais do mesmo e b) casos em que se debate o conceito de refugiado e sua aplicação enquanto direito. Há somente uma decisão que trata dos direitos assegurados aos refugiados pelo Direito Internacional; no entanto, a análise da questão se deu de forma indireta, sendo o assunto principal do acórdão a possibilidade de expedição de registro civil a um estrangeiro.

Muito embora fosse natural que os temas relativos ao refúgio se concentrassem na $1^{\text {a }}$ Seção e suas respectivas turmas $\left(1^{\mathrm{a}}\right.$ e $\left.2^{\mathrm{a}}\right)$, as quais atraem temáticas relativas ao direito público (art. $9^{\circ}$ do Regimento Interno do Superior Tribunal de Justiça), outros órgãos fracionários do STJ decidiram sobre o tema ( $4^{\mathrm{a}}$ e $6^{\mathrm{a}}$ Turmas), exatamente em questões diversas daquelas sobre concessão de refúgio ou expulsão de refugiados ou requerentes. A concentração dos casos na $1^{\text {a }}$ Seção não significou, entretanto, uma uniformização de entendimentos sobre o grau de discricionariedade a ser exercido pelas autoridades brasileiras no momento da concessão do status de refugiado a uma pessoa, muito embora seja possível afirmar um consenso da corte sobre a impossibilidade de o Judiciário rever o mérito do ato administrativo.

Não obstante a lei sobre refugiados ter sido promulgada em 1997, significativa porção dos casos trazidos ao STJ contestando a aplicação de suas regras se concentrou na década de 2010. Dos 13 casos analisados nesta pesquisa, 62\% foram julgados entre 2011-2017, e 38\%, entre 2005-2008. 
A partir da leitura dos casos, não foi possível identificar fatores que pudessem explicar, de forma contundente ou definitiva, a razão pela qual o tema tem sido tão pouco discutido no STJ. Contudo, sugerimos as seguintes hipóteses: a) de que o aumento de casos pós-2010 tenha sido ocasionado pelo julgado do STF na Extradição no 1085 (2010), permitindo a revisão judicial do mérito de concessão do refúgio e b) o aumento no número de solicitações de refúgio no Brasil, especialmente, a partir de $2012^{26}$.

O tema mais recorrente foi o procedimento de concessão do refúgio, com sete decisões, entre acórdãos e decisões monocráticas. Como nelas foi vinculada a ideia de que o controle judicial do procedimento administrativo em apreço não poderia permear o conteúdo material da decisão sobre a concessão do refúgio, podemos afirmar que a maioria da jurisprudência do Superior Tribunal de Justiça está em desacordo com o Direito Constitucional e com a melhor leitura do Direito Internacional, o que é problemático para a proteção dos refugiados e dos solicitantes de refúgio.

Não obstante ser uma categoria do direito internacional, a determinação do status de refugiado varia de acordo com os locais em que se regulamentam os procedimentos para sua concessão (HAMLIN, 2012, p. 933). A discussão que ocorre no âmbito da Administração sobre o cumprimento, ou não, dos critérios para a concessão é importante, porque será ela que fixará, inicialmente, os padrões e precedentes sobre o tema, antes de uma possível revisão judicial (HAMLIN, 2012, p. 936). Porém, uma posição de deferência judicial total à Administração nesta matéria pode implicar violações de direitos, pois poderá reforçar uma tendência de o Estado brasileiro defender o direito soberano de excluir (HAMLIN, 2012, p. 937).

Essa tendência poderá ser objeto de futuras investigações científicas, porquanto, como afirmado alhures, para o STJ, a discricionariedade do ato administrativo de concessão e denegação não se justificaria como um fato, mas como decorrência da soberania do Estado brasileiro, o qual poderá determinar, indiscriminadamente, quem preencherá as condições para a atribuição do status de refugiado, e não como um ato que declara um direito, cujo gozo depende, é verdade, de uma apreciação administrativa prévia realizada por autoridades competentes, mas que poderá ser revista judicialmente por não ser uma questão de oportunidade e conveniência do Estado.

Diferentemente de outras hipóteses de migração, especialmente aquelas influenciadas por perspectivas educacionais e econômicas, a recepção aos refugiados não se caracteriza como uma

\footnotetext{
${ }^{26}$ Conferir os dados sobre o refúgio no Brasil constantes do relatório Refúgio em Números (BRASIL, 2017, p. 16). Solicitações recebidas pelo Brasil por ano: 4.022 em 2012, 17.631 em 2013, 28.385 em 2014, 28.670 em $2015,10.308$ em 2016 e 33.866 em 2017.
} 
política pública condicionada por escolhas do Executivo, mas de um direito a ser garantido pelo Estado brasileiro, o que, por certo, inclui o Poder Judiciário.

\section{CONCLUSÃO}

Por todo o exposto, a ideia da judicialização como forma de corrigir eventual atuação dos Poderes Executivo e Legislativo contrária ao Direito e, no caso do refúgio, contrária a um direito amplamente assegurado no âmbito internacional e no interno, é plenamente válida com vistas a garantir a efetivação do mesmo. Como instrumento de garantia da proteção integral aos refugiados, o recurso ao Poder Judiciário pode auxiliar no avanço do respeito a um direito que decorre da dignidade humana, um dos princípios mais importantes do Estado Democrático.

Doutro modo, no Brasil percebe-se que a judicialização do refúgio, em sua maioria, não é vista sob esta perspectiva. À exceção de alguns julgados específicos do STF, o Poder Judiciário brasileiro, por entender ser indevida sua ingerência no tema, tende a deferir os casos ao Executivo, posicionamento que não merece prosperar. É imperioso que os tribunais nacionais se conscientizem acerca do caráter jurídico do refúgio e, consequentemente, de sua competência para apreciar a matéria, a fim de exercer de maneira efetiva seu papel na concretização desse direito humano tão relevante.

\section{REFERÊNCIAS}

ALMEIDA, Pedro de Paula Lopes Almeida. O reconhecimento da condição de refugiado perante o Direito Brasileiro dos cidadãos iranianos acusados de apostasia. Revista da Defensoria Pública da União, Brasília, n. 6, p. 138-159, dez. 2013.

ALTO COMISSARIADO DAS NAÇÕES UNIDAS PARA REFUGIADOS (ACNUR). Manual de Procedimentos e Critérios para a Determinação da Condição de Refugiado. 2013. Disponível em: http://bit.ly/2IrbDPf. Acesso em: 15 ago. 2017.

AMARAL, Ana Paula Martins; COSTA, Luiz Rosado. A (não) criminalização das migrações e políticas migratórias no Brasil: do Estatuto do Estrangeiro à nova Lei de Migração. Revista Justiça do Direito, v. 31, n. 2, p. 208-228, maio - ago. 2017.

BRASIL. Constituição (1988). Constituição da República Federativa do Brasil de 1998. Disponível em: http://bit.ly/2IMRxyp. Acesso em: 8 jan. 2018.

BRASIL. Lei n. 13.445, de 24 de maio de 2017. Institui a Lei de Migração. Disponível em: http://bit.ly/2Dj23cY. Acesso em: 8 jan. 2018. 
BRASIL. Lei n. 6.015, de 31 de dezembro de 1973. Dispõe sobre os registros públicos, e dá outras providências. Disponível em: http://bit.ly/2Gr6rqX. Acesso em: 30 jan. 2019.

BRASIL. Lei n. 6.815, de 19 de agosto de 1980. Define a situação jurídica do estrangeiro no Brasil, cria o Conselho Nacional de Migração. Disponível em: http://bit.ly/2UtZyu0. Acesso em: 8 jan. 2018.

BRASIL. Lei n. 9.474, de 22 de julho de 1997. Define mecanismos para a implementação do Estatuto dos Refugiados de 1951, e determina outras providências. Disponível em: http://bit.ly/2Pk8ils. Acesso em: 8 jan. 2018.

BRASIL. Lei n. 9.784, de 29 de janeiro de 1999. Regula o processo administrativo no âmbito da Administração Pública Federal. Disponível em: http://bit.ly/2XnT6qr. Acesso em: 30 jan. 2019.

BRASIL. Superior Tribunal de Justiça. Regimento Interno do STJ. Atualizado até a Emenda Regimental n. 30 de 22 de maio de 2018. Brasília, STJ, 2018. Disponível em: http://bit.ly/2v9IKhX. Acesso em: 30 jan. 2019.

BRASIL. Supremo Tribunal Federal. Extradição n. 1008/CB - Colômbia. Relator: Ministro Gilmar Mendes. Pesquisa de Jurisprudência. Acórdãos. Disponível em: http://bit.ly/2GwaG61. Acesso em: 30 jan. 2019.

BRASIL. Supremo Tribunal Federal. Extradição n. 1085/República Italiana. Relator: Ministro Cezar Peluso. Pesquisa de Jurisprudência. Acórdãos. Disponível em: http://bit.ly/2XmMAQF. Acesso em: 30 jan. 2019.

BRASIL. Supremo Tribunal Federal. Extradição n. 1126/República Federal da Alemanha. Relator: Ministro Joaquim Barbosa. Pesquisa de Jurisprudência. Acórdãos. Disponível em: http://bit.ly/2DlFYud. Acesso em: 30 jan. 2019.

BRASIL. Supremo Tribunal Federal. Súmula Vinculante 5. A falta de defesa técnica por advogado no processo administrativo disciplinar não ofende a Constituição. Sessão Plenária de 07/05/2008. DJe de 16.5.2008. Disponível em: http://bit.ly/2ULjKg0. Acesso em: 8 jan. 2018.

CORTE INTERAMERICANA DE DIREITOS HUMANOS. Caso Família Pacheco Tineo v. Estado Plurinacional de Bolívia. Objeções Preliminares, Mérito, Reparações e Custos. Julgamento em 25 de novembro de 2013. Disponível em: http://bit.ly/2UukO2J. Acesso em: 12 dez. 2017.

CORTE INTERAMERICANA DE DIREITOS HUMANOS. Opinião Consultiva OC 16-99. El derecho a la información sobre la asistencia consular en el marco de las garantías del debido proceso legal. Costa Rica, 1999. Disponível em: http://bit.ly/2GpS32a. Acesso em: 30 jan. 2019.

DINIZ, Irene Bogado; PEREIRA, Marcos Vinícius Torres. Uma análise da jurisprudência do Supremo Tribunal Federal sobre a extradição: o Brasil não é o paraíso para os criminosos estrangeiros. Cosmopolitan Law Journal, v. 2, n. 1, jun. 2014, p. 168-198.

HAMLIN, Rebecca. International law and administrative insulation: A comparison of refugee status determination regimes in the United States, Canada and Australia. Law \& Social Inquiry, Vol. 37, No. 4 (2012), pp. 933-968. 
HATHAWAY, James C. The Rights of Refugees under International Law. Cambridge, UK: Cambridge University Press, 2005.

JUBILUT, Liliana Lyra. A Judicialização do Refúgio. In: RAMOS, André de Carvalho; RODRIGUES, Gilberto; ALMEIDA, Guilherme Assis de. 60 anos de ACNUR: perspectivas de futuro. São Paulo: Editora CL-A Cultural, 2011.

MENDES, Gilmar Ferreira. Direito de Nacionalidade e Regime Jurídico do Estrangeiro. Direito Público. Porto Alegre, v. 4, n. 14, p. 5-19, out. - dez. 2006.

MORAES, Thaís Guedes Alcoforado de. O papel do judiciário na proteção aos refugiados. Revista da Faculdade de Direito da UFRGS, Porto Alegre, n. 32 (Volume especial - Comemorativo ao Lançamento da Cátedra Sérgio Vieira de Mello), p. 164-181, jan. 2014.

ORGANIZAÇÃO DAS NAÇÕES UNIDAS. Convenção das Nações Unidas relativa ao Estatuto dos Refugiados de 1951. Disponível em: http://bit.ly/2UnJIBm. Acesso em: 15 jul. 2017.

ORGANIZAÇÃO DAS NAÇÕES UNIDAS. Convenção de Viena sobre Relações Consulares. Disponível em: http://bit.ly/2Dm11wG. Acesso em: 30 jan. 2019.

ORGANIZAÇÃO DAS NAÇÕES UNIDAS. Protocolo de 1967 relativo ao Estatuto dos

Refugiados. Disponível em: http://bit.ly/2KOGUh4. Acesso em: 15 jul. 2017.

RAMOS, André de Carvalho. Novas Tendências do Direito dos Refugiados no Brasil. In: JUBILUT, Liliana Lyra; GODOY, Gabriel Gualano de (org.). Refúgio no Brasil: Comentários à Lei 9.474/97. São Paulo: Quartier Latin/ACNUR, 2017, p. 273-303.

SCOTT, W. Richard. Institutional theory. In: RITZER, George (org.). Encyclopedia of Social Theory. Vol. I. California: Sage, 2004. p. 408-414.

VELLOSO, Carlos Mário da Silva. Natureza jurídica do ato concessivo do status de refugiado e seu controle pelo Poder Judiciário. Revista de Direito Administrativo. Belo Horizonte, n. 250, p. 257291, jan./abr. 2009.

Breno Baía Magalhães Mestre e Doutor em Direito pela Universidade Federal do Pará (UFPA), Professor Adjunto na mesma instituição.E-mail: brenobaiamag@gmail.com

Gabriella Thaís Sousa Corrêa Bacharel em Direito pela Universidade Federal do Pará (UFPA). Advogada. E-mail: gabriella_tsc@hotmail.com 